\title{
Badanie wyborcze realizowane w dniu wyborów prezydenckich w 2010 roku jako przykład badania realizowanego w miejscu publicznym
}

Election survey carried out on the presidential election in 2010 as an example of a survey carried out in a public place

Stowa kluczowe: exit poll, badanie $w$ dniu wyborów, badanie CATI, sondaż przedwyborczy

Keywords: exit poll, election day survey, CATI survey, pre-election survey

\begin{abstract}
Abstrakt: W ramach artykutu Autor przedstawia wady $i$ zalety rozwiazań badawczych zastosowanych w czasie wyborów prezydenckich w 2010 roku. Decyzja o wyborze akurat tych wyborów jako przykładu podyktowana była, z jednej strony faktem, że badanie $w$ dniu wyborów realizowaty trzy firmy, a z drugiej - że zastosowano różne techniki badawcze. Ponadto, przeprowadzone badania są dobrze udokumentowane, zarówno $w$ publicystyce, jak i raporcie zespotu profesora Domańskiego oraz przez samego Autora, który analizowat ten problem pod katem doboru odpowiedniej techniki badawczej już wcześniej.
\end{abstract}

Abstract: As part of the article, the author presents the advantages and disadvantages of research solutions used during the presidential election in 2010. The decision to choose these elections as an example was dictated, on the one hand, by the fact that the survey on the day of the election was carried out by three companies, and on the other hand, by the fact that different research techniques were used. Moreover, the conducted research is well documented both in the journalism and in the report of Professor Domanski's team, and by the author himself, who analyzed this problem in terms of the selection of an appropriate research technique earlier.

* ORCID ID: https://orcid.org/0000-0001-7159-6903, doktorant Akademii Pedagogiki Specjalnej im. Marii Grzegorzewskiej w Warszawie. Od 2005 r. związany z badaniami marketingowymi, a od 2008 r. - społecznymi i ewaluacyjnymi. E-mail: kkuzma@aps.edu.pl. 


\section{Wprowadzenie}

Badanie wyborcze exit poll jest jednym z dwóch badań realizowanych w miejscach publicznych. Badania przeprowadzane w miejscach publicznych dzielą się na dwa rodzaje ze względu na miejsce realizacji wywiadu. W przypadku krótkich, nieprzekraczających 20 minut $^{1}$ sondaży ulicznych, ankieter będzie realizował badanie w miejscu, gdzie istnieje największa szansa znalezienia osób odpowiadających profilowi respondenta $^{2}$. Drugim typem badań są badania realizowane w miejscach ściśle określonych, zaś każde odstępstwo od tej zasady powoduje konsekwencje dla ankietera - od nieuznania całości lub części wywiadów, aż do rozwiązania współpracy z agencją badawczą ${ }^{3}$.

Tabela 1. Różnice pomiędzy badaniami exit poll a badaniami przedwyborczymi

1. Grupą docelową badania exit poll nie są osoby uprawnione do głosowania, ale wyborcy, czyli osoby, które już oddały swój głos. Przewidywanie wyników wyborów w oparciu o sondaże przedwyborcze jest obarczone większym błędem z dwóch powodów: po pierwsze, w sondażach przedwyborczych biorą udział również osoby, które nie wezmą w rzeczywistości udziału w głosowaniu, po drugie, z powodu nierównomiernego rozkładu frekwencji osób popierających poszczególne partie, ale niebiorących udziału w głosowaniu.

2. W badaniu exit poll mamy do czynienia z rzeczywistymi zachowaniami, a nie deklaracjami. W badaniu exit poll nie pytamy o to, jak badany zamierza głosować, ale o to jak w rzeczywistości zagłosował.

3. Cała sytuacja jest w pełni przejrzysta dla respondentów. Łatwo jest im zrozumieć zarówno cel badania, jak i zastosowanie uzyskanych wyników. Problem braków odpowiedzi, który często pojawia się w sondażach w przypadku badania exit poll jest niewielki, a w rzeczywistości pomijalny.

4. Z uwagi na fakt, że głosowanie odbyło się chwilę wcześniej, nie istnieje problem z pamięcią respondenta, bardzo częsty w przypadku pytań o fakty z przeszłości. W badaniu exit poll rozmawiamy z respondentem chwilę po oddaniu głosu, dzięki czemu możemy w ankiecie odtworzyć nawet skomplikowany sposób głosowania.

Źródło: opracowanie własne na podstawie R. Hilmer, Exit Polls - A Lot More than Just a Tool for Election Forecasts, [w:] M. Carballo, U. Hjelmar (red.), Public Opinion Polling in a Globalized World, Berlin 2008, s. 95.

1 Praktyka badawcza pokazuje, że jest najlepiej, aby sondaż uliczny nie przekraczał 10-15 minut. Jest to również uzależnione od tematyki badania.

2 P.B. Sztabiński, Z. Sawiński, F. Sztabiński, Nowe metody, nowe podejścia badawcze $w$ naukach społecznych, Warszawa 2004, s. 254.

3 Tamże, s. 254. 
Jednym z typów badań realizowanych w ściśle określonych miejscach są badania exit poll. Ten rodzaj badań jest realizowany pośród osób wychodzących z lokali wyborczych po oddaniu głosów ${ }^{4}$. Duża dokładność badań exit poll wynika z fundamentalnych różnic w stosunku do zwykłych badań sondażowych. Najważniejsze różnice zostały zebrane w tabeli 1 .

W badaniu exit poll należy zagwarantować taką samą możliwość wejścia do próby dla każdego respondenta. W przypadku badania exit poll jest to realizowane za pomocą doboru losowo-systematycznego. W pierwszym kroku wybieramy sobie tzw. punkt startowy (w tym wypadku komisję wyborczą), natomiast w drugim skupiamy się już na samych wyborcach. Komisje wyborcze, w których jest realizowane badanie powinny liczyć, co najmniej 90 uprawnionych do głosowania. Ankieter rozmawia, z co n-tym wyborca, który opuścił lokal wyborczy. Odstępy pomiędzy wyborcami są określane na podstawie spodziewanej frekwencji i całkowitej liczby wywiadów. Odstęp pomiędzy kolejnymi respondentami może wynosić 10 lub więcej osób.

Zastosowana w tym wypadku próba jest próbą losową systematyczną, a w każdym z okręgów, w których realizuje się badanie losuje się taką samą proporcję wyborców. Ze względu na fakt niedostosowania liczby respondentów do liczby uprawnionych do głosowania, istnieje niebezpieczeństwo, iż wyniki przeprowadzonego badania nie będą dokładne. Wynika to z faktu, iż np. w okręgu gdzie jest dwieście osób uprawnionych do głosowania, zostanie zaproszonych do udziału w badaniu około dziesięciu osób. Frekwencja wyborcza oscyluje bowiem w okolicach 50\%. Niestety, dziesięć osób to zbyt mało, aby można było wnioskować o zachowaniach wyborczych w pojedynczej komisji. Ponadto - ponieważ próba dobierana jest w sposób losowy systematyczny - może ona nie być reprezentatywna 5 .

W opisanym powyżej sposobie badania nie jest brana pod uwage liczba uprawnionych do głosowania, co skutkuje jednakowym prawdopodobieństwem wejścia poszczególnych respondentów do próby.

Wielkość próby zależy od systemu głosowania (np. okręgi jednomandatowe vs. wielomandatowe), wielkości państwa oraz okręgów wyborczych, dla których są wymagane prognozy. W większości przypadków konieczna jest duża liczba okręgów wyborczych, ponieważ potrzebne są dane na poziomie regionalnym, a nie krajowym. Dobrym przykładem

4 Tamże, s. 254.

5 R. Hilmer, Exit Polls - A Lot More than Just a Tool for Election Forecasts, [w:] M. Carballo, U. Hjelmar (red.), Public Opinion Polling in a Globalized World, Berlin 2008, s. 96-97. 
może być np. badanie exit poll realizowane w 1992 r. w dniu wyborów parlamentarnych w Stanach Zjednoczonych. Badaniem objęto 1310 okręgów wyborczych, łącznie udział w badaniu wzięło 177000 respondentów 6 . Jednakże z uwagi na duże koszty takie badania realizuje się relatywnie rzadko ${ }^{7}$.

Badanie exit poll pozwala dostarczyć w wieczór wyborczy bardzo dokładnych prognoz poparcia dla partii lub kandydatów. Pomimo iż jest to najważniejsze dla stacji telewizyjnych, które najczęściej płacą za prowadzenie tych badań, na ich podstawie można również opisać z dużą dokładnością wzorce poparcia dla poszczególnych kandydatów ${ }^{8}$. Jest to szczególnie ciekawe, kiedy możemy porównać wyniki np. z poprzednimi wyborami. W ramach badania exit poll zbiera się również informacje społeczno-demograficzne, takie jak np. płeć respondentów, ich wiek, poziom wykształcenia, przynależność do określonych narodowości ${ }^{9}$, przynależność do określonych grup religijnych ${ }^{10}$. Na podstawie danych społeczno-demograficznych oraz odpowiednio dużej grupy respondentów można formułować wiarygodne wnioski, dotyczące nawet bardzo specyficznych podgrup, np. „młodzi, bardzo dobrze wykształceni, z małych ośrodków wiejskich"11.

Podsumowując, badania exit poll są unikalnym narzędziem, pozwalającym na uzyskanie wiarygodnej i dopracowanej bazy danych na temat zachowań wyborczych. Dzięki nim uzyskujemy informacje na temat motywów i struktury wyborców każdej z partii. Tym samym badania te stanowią nieocenione źródło wiedzy dla politologów, socjologów, mediów, a także dla polityków i ich doradców. Charakter badania exit poll, jako narzędzia działającego w czasie rzeczywistym, pozwala na dyskusję i komentowanie wyników wyborów natychmiast po zamknięciu lokali wyborczych. Wyniki takiego badania są interesujące dla ludzi i zachęcają ich do oglądania studia wyborczego nadawanego równolegle przez konkurujące ze sobą stacje telewizyjne. Wyniki badań exit poll są w pewnym

6 Zob. W. Mitofsky, M. Edelmann, A Review of the 1992 VRS Exit Polls, Paper Prepared for Presentation at the Annual Meeting of the Annual Meeting of the American Association for Public Opinion Research. May 20-23. St. Charles, Illinois 1993.

7 R. Hilmer, Exit Polls..., s. 98.

8 Również partii politycznych.

9 Praktykowane głównie w takich krajach jak USA czy Szwajcaria. TNS OBOP/TNS Polska takich danych nie zbiera ze względu na monokulturowość Polski.

10 Również niepraktykowane przez TNS Polska.

11 Zob. R. Hilmer, Exit Polls..., s. 105. 
stopniu jednym z elementów demokracji, ponieważ mogą one uzupełniać niezależną kontrolę liczenia głosów ${ }^{12}$.

Do roku 2010 jedną z dwóch firm, które realizowały badania w dniu wyborów (badania typu exit poll) był Ośrodek Badania Opinii Publicznej ${ }^{13}$. Pierwsze badanie exit poll OBOP przeprowadził we współpracy z niemieckim instytutem badawczym INFAS w czasie pierwszych demokratycznych wyborów prezydenckich w 1990 r. Po raz pierwszy konkurencja, inna niż badania exit poll PBS-u, dla OBOP-u pojawiła się w czasie analizowanych wyborów prezydenckich w 2010 r. Dopiero wtedy komercyjne stacje telewizyjne TVN i Polsat zdecydowały się zamówić badanie w dniu wyborów. Ze względu na związki OBOP-u z telewizją publiczną TVP (do 2011 r. TVP posiadała 40\% udziałów w OBOP) obydwie stacje musiały skorzystać z oferty firm konkurencyjnych - szczegóły w tabeli 2 poniżej. Dopiero w wyborach parlamentarnych w 2011 r. możliwe było wspólne przeprowadzenie badania exit poll dla dwóch telewizji: TVP i TVN. Obecnie badania takie - na potrzeby wszystkich stacji telewizyjnych ${ }^{14}$ - prowadzi firma Ipsos Polska która zatrudnia większość zespołu dawnego Ośrodka Badania Opinii Publicznej.

Tabela 2. Zestawienie firm badawczych oraz stacji telewizyjnych zlecających badanie w dniu wyborów

\begin{tabular}{|l|l|}
\hline \multicolumn{1}{|c|}{ Firma badawcza } & $\begin{array}{c}\text { Stacja telewizyjna na zlecenie, której } \\
\text { realizowane było badanie }\end{array}$ \\
\hline Ośrodek Badania Opinii Publicznej (OBOP) & Telewizja Polska (TVP) \\
\hline Millward Brown SMG/KRG (MB SMG/KRC) & TVN / TVN24 \\
\hline Instytut Homo Homini (IHH) & Polsat / Polsat News \\
\hline
\end{tabular}

Źródło: opracowanie własne na podstawie materiałów prasowych.

Pierwotny termin, w którym miały odbyć się analizowane w artykule wybory prezydenckie był wyznaczony przez daty graniczne - 19 września i 3 października 2010 r. Wiązało się to z upływem w dniu 23 grudnia kadencji ówcześnie urzędującego prezydenta, Lecha Kaczyńskiego. Po katastrofie w dniu 10 kwietnia rządowego samolotu na lotnisku Siewiernyj w Smoleńsku i śmierci prezydenta Lecha Kaczyńskiego, marszałek

12 Zob. tamże, s. 107.

13 Do roku 2010 tylko TNS OBOP i PBS prowadziły w Polsce badania exit poll w czasie wyborów parlamentarnych i prezydenckich.

14 Telewizja Polska, TVN/TVN24 oraz Polsat/Polsat News. 
Sejmu, Bronisław Komorowski - zgodnie z Konstytucją zobowiązany był wyznaczyć, w ciągu 14 dni od opróżnienia urzędu, termin przyśpieszonych wyborów (art. 7 pkt. 2 ustawy o wyborze Prezydenta RP z dnia 27 września 1990 r.). Zgodnie z obowiązującymi przepisami (zawartymi w Konstytucji RP i ustawie o wyborze Prezydenta RP) termin wyborów został wyznaczony 21 kwietnia na dzień 20 czerwca. W przypadku, gdyby żaden z kandydatów nie zdobył ponad połowy głosów, druga tura wyborów z udziałem dwóch kandydatów, którzy uzyskali największą ilość głosów miałaby odbyć się 14 dni później, w dniu 4 lipca (art. 8b pkt. 1 wspomnianej ustawy).

\section{I tura wyborów - 20 czerwca $2010 \mathrm{r}$.}

W pierwszej turze wyborów, 20 czerwca, badanie w dniu wyborów było realizowane na dwa sposoby. Ośrodek Badania Opinii Publicznej w pierwszej turze realizował badanie metodą exit poll, zaś MB SMG/KRC oraz Instytut Homo Homini zdecydowały się na przeprowadzenie badania metodą CATI (wywiadu telefonicznego). Opis próby, doboru respondentów oraz transmisji i przetwarzania danych w badaniu exit poll OBOP, został opracowany na podstawie wewnętrznych materiałów firmy. $\mathrm{Ze}$ względu na fakt, iż znaczna część informacji stanowi tajemnicę przedsiębiorstwa, poniższy opis jest uproszczony i nie zawiera szczegółowych rozwiązań technicznych. Badania MB SMG/KRC oraz Instytutu Homo Homini zostaną omówione w oparciu o dostępne materiały prasowe, ponieważ żadna z firm nie zgodziła się na udostępnienie zastosowanych w przeprowadzonych badaniach rozwiązań.

\section{Badanie exit poll - TNS OBOP}

Badanie OBOP było realizowane na losowej próbie 500 obwodowych komisji wyborczych. Dobór próby miał charakter warstwowy proporcjonalny, gdzie warstwy stanowiły skrzyżowanie okręgu oraz województwa z kategorią wielkości miejscowości. Oprócz tego kontrolowane były warstwy wynikające z wielkości obwodu głosowania. Każda komisja była losowana z prawdopodobieństwem równym udziałowi danej komisji wśród wszystkich komisji składających się na daną warstwę. Taki sposób doboru próby spełniał fundamentalny warunek losowości próby i pozwolił na zapewnienie każdemu wyborcy znanego prawdopodobieństwa uczestnic- 
twa w badaniu. Ponadto, losowanie warstwowe proporcjonalne, stosowane w przypadku, gdy chcemy zapewnić lepszą reprezentatywność, w znacznym stopniu redukuje błąd oszacowania, w porównaniu do losowania prostego. W przypadku losowania prostego istnieją dwa możliwe błędy, pierwszy to błąd z próby wewnątrz każdej z wyróżnionych warstw, zaś drugi to błąd pomiędzy poszczególnymi warstwami, odnoszący się do liczebności.

W przypadku losowania prostego możemy wybrać do próby bardzo nietypowego respondenta lub też możemy wybrać zbyt wielu lub zbyt mało określonych respondentów (np. kobiet, osób z wyższym wykształceniem). W przypadku losowania warstwowego eliminuje się zróżnicowanie pomiędzy warstwami. Ponadto, gdyby wszystkie warstwy były jednorodne, losowanie proporcjonalne zawsze dałoby wynik prawidłowy, co nie jest możliwe w przypadku losowania prostego. Jednakże patrząc z drugiej strony, jeśli podział na warstwy jest całkowicie losowy, to nie daje on żadnych korzyści. Jeśli jednak zmienna, będąca kryterium podziału na poszczególne warstwy jest silnie skorelowana ze zmienną badaną (np. wielkość miejscowości ma istotny wpływ, co widać w przypadku wyników pierwszej tury wyborów prezydenckich w 2010 r. dostępnych na stronie PKW, gdzie J. Kaczyński zdobył więcej głosów na wsiach, zaś B. Komorowski w miastach, czy województwo, np. w województwie lubelskim - w którym była największa różnica w \% uzyskanych głosów przez J. Kaczyńskiego i B. Komorowskiego - ten pierwszy uzyskał o ponad $25 \%$ mniej głosów niż drugi) to zysk z warstwowania jest bardzo duży ${ }^{15}$.

Z oczywistych względów, przy odpowiednio dużej próbie podobne wyniki uda się uzyskać również z próby przygotowanej w losowaniu prostym. Niemniej jednak wprowadzenie warstw do schematu przygotowania próby nie komplikuje w dużym stopniu analizy danych uzyskanych w przeprowadzonym badaniu. W przypadku losowania warstwowego jest bardzo istotne, aby znać strukturę badanej populacji pod względem zmiennej grupującej. Nie możemy tworzyć warstw w oparciu o zmienne, o których nie mamy informacji lub gdy są one nieprecyzyjne. Ponadto, podział na warstwy najczęściej robi się tylko uwzględniając proste zmienne, takie jak np.: płeć, wiek, wykształcenie. Zmienne można ze sobą krzyżować, ale rzadko będzie korzystne dzielenie populacji według więcej niż dwóch zmiennych jednocześnie. Pomimo iż warstwowanie ma swoje ograniczenia, jest jednocześnie bardzo prostą procedurą, której zalety należy zawsze wykorzystywać ${ }^{16}$.

15 H.M. Blalock, Statystyka dla socjologów, Warszawa 1977, s. 448-449.

16 Tamże, s. 449. 
Pomimo iż zgodnie z literaturą metodologiczną, badania exit poll powinny być realizowane w oparciu o próbę warstwową proporcjonalną, w badaniu wykonanym przez TNS OBOP w czasie wyborów prezydenckich zastosowano dobór warstwowy nieproporcjonalny. Oznacza to, że w przypadku mniejszych lokali wyborcy mieli większe prawdopodobieństwo trafienia do próby niż w lokalach dużych. Podyktowane to było chęcią uzyskania takiej samej (lub bardzo zbliżonej) liczby respondentów w każdym z lokali wyborczych objętych badaniem.

Każdy z wylosowanych lokali wyborczych był obsługiwany przez zespół ankieterów. Zadaniem ankieterów było dokładne zliczanie osób wychodzących z lokali wyborczych stosując specjalne liczniki przygotowane przez Sekcję Prób i Analiz TNS OBOP. Wielkość licznika została dobrana w taki sposób, aby zapewnić odpowiednią reprezentację osób głosujących w danym lokalu wyborczym. Na podstawie prawie dwudziestoletnich doświadczeń OBOP zrezygnował z licznika, co dziesiąty (lub rzadziej) wyborca, które sprawdzają się w przypadku krajów takich jak Stany Zjednoczone, na rzecz liczników o mniejszym „skoku”. W czasie wyborów prezydenckich w 2010 r. ankieterzy TNS OBOP zapraszali do wzięcia udziału w badaniu, średnio, co czwartą osobę wychodzącą z lokalu wyborczego. W większych komisjach wyborczych mogła to być, maksymalnie, co ósma osoba, zaś w najmniejszych komisjach - maksymalnie, co druga osoba opuszczająca lokal wyborczy. Oznacza to, iż ankieterzy mogli zaprosić do badania maksymalnie 12,5\% uprawnionych do głosowania w największych komisjach oraz maksymalnie 50\% uprawnionych do głosowania w małych komisjach. Każda osoba była proszona o wypełnienie krótkiej ankiety, która była uproszczoną wersją karty do głosowania. Ponadto w ankiecie znalazły się również pytania dotyczące cech społeczno-demograficznych osób wypełniających ankietę. Po samodzielnym wypełnieniu respondent wrzucał ankietę do urny-pudełka z logo TNS OBOP. Taka procedura miała dać respondentom poczucie anonimowości.

O ściśle określonych porach ankieterzy mieli opróżniać urny i przesyłać wyniki do centrum obliczeniowego TNS OBOP. Transmisja danych odbywała się przy użyciu telefonów GSM wyposażonych w specjalną aplikację, która weryfikowała wprowadzone przez ankietera dane pod kątem poprawności formalnej i merytorycznej. Ze względu na fakt, iż sama aplikacja użyta w badaniu stanowi tajemnicę przedsiębiorstwa mogę powiedzieć tylko, iż miała ona ograniczenie zakresu liczb, które można było wprowadzić oraz liczby odpowiedzi. W przypadku wykrycia błędu system automatycznie informował ankietera o błędzie i prosił o ponowne 
wprowadzenie danych. System podstawowy (GSM + aplikacja) został zduplikowany i w dniu wyborów zostało uruchomione studio Call Center, które pozwalało na zebranie danych od ankieterów w przypadku awarii systemu podstawowego. Do przesyłu danych wykorzystano szyfrowany protokół komunikacyjny SSH wersja 2, wykorzystujący do szyfrowania algorytm AES ${ }^{17}$. Analiza przesłanych danych była realizowana przez trzy pracujące niezależnie zespoły. Jeden z zespołów wykorzystywał do analiz pakiet statystyczny SPSS, dwa pozostałe - autorskie systemy obliczeniowe TNS OBOP. Dopiero uzyskanie takich samych wyników przez każdy z zespołów kwalifikowało je do publikacji. Przyjęto również, że w przypadku rozbieżności - analizy zostaną powtórzone, a jednocześnie zespół wspierający przeprowadzi weryfikację pracy ankieterów.

\section{Badanie telefoniczne - Millward Brown SMG/KRC}

Badanie MB SMG/KRC dla TVN, przeprowadzone w pierwszej turze wyborów, było badaniem telefonicznym, realizowanym na próbie 6000 respondentów, którzy już oddali głos. Sondaż przeprowadzono na mieszanej próbie numerów stacjonarnych i komórkowych w dniu wyborów w ciągu ostatnich trzech godzin trwania głosowania (17.00-20.00). Zarówno w materiałach prasowych, jak i w raporcie „Ocena metodologii i rezultatów badań poprzedzających pierwszą i drugą turę wyborów prezydenckich w 2010 roku” przygotowanych na zlecenie OFBOR przez Komisję pod kierownictwem profesora Henryka Domańskiego nie ma informacji o szczegółowym doborze próby. Zgodnie z oceną komisji profesora Domańskiego, firma ograniczyła się do przekazania informacji, iż badanie zostało przeprowadzone na „standardowej próbie CATI”. W oparciu o moje doświadczenie badawcze uważam, iż można bezpiecznie założyć, że próba do badania telefonicznego została przez MB SMG/KRC dobrana w sposób reprezentatywny, tzn. że jej wyniki powinno dać się uogólnić na grupę Polaków w wieku 18 lat i więcej. Wydaje się również, iż próba była reprezentatywna ze względu na region (lub województwo) oraz klasę wielkości miejscowości18.

17 Szczegóły znajdują się w dokumencie RFC 4250.

18 Szerzej na temat doboru próby w badaniach CATI, gdzie Autor wyciąga tożsame wnioski: D. Mider, Polacy wobec przemocy politycznej. Studium typów postaw i ocen moralnych, Warszawa 2017, s. 143-152. 


\section{Badanie telefoniczne - Instytut Homo Homini}

Na zlecenie telewizji Polsat badanie telefoniczne w dniu wyborów zrealizował Instytut Homo Homini. Badanie zostało zrealizowane w dniu wyborów na próbie 5000 dorosłych Polaków. W informacjach prasowych brakuje szczegółów dotyczących doboru próby (np. czy badanie było realizowane tylko na próbie użytkowników telefonów stacjonarnych czy również komórkowych) oraz jej reprezentatywności. Badanie Instytutu Homo Homini nie zostało również uwzględnione w „Ocenie...” profesora Domańskiego. Ponieważ badanie było uogólniane na populację Polaków próba do niego powinna być reprezentatywna, co najmniej ze względu na płeć, wiek oraz miejsce zamieszkania - region (województwo) i klasę wielkości miejscowości.

Próba dobrana w sposób reprezentatywny dla zbiorowości wyborców pozwalała na uogólnianie wyników dla tej zbiorowości. Niemniej jednak taka próba nie uwzględnia np. frekwencji wyborczej w poszczególnych regionach (województwach) i nie może być uogólniana na populację osób, które w rzeczywistości oddały już swój głos. Wyniki I tury wyborów prezydenckich przedstawia tabela poniżej. Ponadto, np. w przypadku badania MB SMG/KRC średnio, co czternasty respondent odmówił odpowiedzi na pytanie, na kogo oddał swój głos. Ważny jest również response rate, tj. liczba osób, które wyraziły w ogóle zgodę na wzięcie udziału w badaniu. MB SMG/KRC podało, że response rate w przeprowadzonym przez nich badaniu telefonicznym zawierał się w przedziale od 7\% do 15\%. W przypadku badania exit poll realizowanego przez OBOP response rate przekroczył 90\%19. Poza wysokim odsetkiem response rate w badaniu exit poll OBOP-u, z możliwości odmowy odpowiedzi na pytanie na kogo respondent oddał swój głos w wyborach skorzystało poniżej 0,5\% respondentów.

Niestety nie wiemy, co MB SMG/KRC robiło w przypadku respondentów, którzy odmówili udzielenia odpowiedzi na pytanie, na kogo oddali swój głos. Możliwe są trzy rozwiązania:

1. Wyłączenie tych odpowiedzi z analiz, co oznacza, iż rzeczywista wielkość próby jest mniejsza niż deklarowana $(\mathrm{N}=5580$ zamiast $\mathrm{N}=6000)$;

2. Proporcjonalne rozłożenie tych odpowiedzi na wszystkich kandydatów, co może stanowić zagrożenie przeszacowania wyników dla kandydatów o najmniejszym poparciu lub też nie uwzględnienie ich

19 H. Domański, Ocena metodologii i rezultatów badań poprzedzających pierwsza i druga turę wyborów prezydenckich w 2010 roku, OFBOR, Warszawa 2010. 
w ogóle, tak jak to miało miejsce w badaniu IHH, gdzie dwóch kandydatów (Bogusław Ziętek i Kornel Morawiecki) miało zerowe poparcie, pomimo iż według danych PKW uzyskali oni niewielki odsetek głosów (odpowiednio: $0,18 \%$ oraz $0,13 \%$ );

3. Wykorzystanie do estymacji modelu zbudowanego w oparciu o posiadaną wiedzę na temat respondentów, którzy odmawiają odpowiedzi w badaniach dotyczących preferencji politycznych.

Wyłączenie pewnych odpowiedzi z analiz skutkuje zmniejszeniem liczebności oraz zaburzeniem losowości próby. Jeśli natomiast będziemy próbować rozłożyć odsetek kategorii „nie wiem/trudno powiedzieć” oraz kategorii „odmowa odpowiedzi” proporcjonalnie na wszystkich kandydatów, możemy doprowadzić do zafałszowania obrazu. Coś takiego miało miejsce w przypadku wszystkich sondaży telefonicznych MB SMG/KRC przed I turą wyborów oraz w dniu 20 czerwca 2010 r. Najbezpieczniejszym rozwiązaniem, z punktu widzenia przewidywania odpowiedzi respondentów, którzy udzielili odpowiedzi ucieczkowych, jest wykorzystanie modelu estymacyjnego, ale według mojej wiedzy obecnie tylko dwie firmy dysponują autorskim modelem umożliwiającym takie działania. Są to TNS Polska SA (firma, która powstała w 2012 r. z połączenia TNS OBOP sp. z o.o. oraz TNS Pentor SA) oraz CBOS, czyli de facto firmy, które badań preferencji wyborczych robią dużo i zebrały informacje na temat grupy osób korzystających z odpowiedzi ucieczkowych w badaniach politycznych.

Tabela 3. Zestawienie wyników sondaży zrealizowanych w dniu 20 czerwca $2010 \mathrm{r}$. z wynikami PKW

\begin{tabular}{|c|c|c|c|c|c|}
\hline & & OBOP & $\begin{array}{c}\mathrm{MB} \\
\mathrm{SMG} / \mathrm{KRC}\end{array}$ & IHH & PKW \\
\hline Sposób re & alizacji badania & Exit Poll & CATI & CATI & $\longrightarrow$ \\
\hline Wielkość & próby & ok. 50000 & 6000 & 5000 & - \\
\hline & $\begin{array}{l}\text { Bronisław } \\
\text { Komorowski }\end{array}$ & $\begin{array}{c}40,7 \% \\
(-0,8 \%)\end{array}$ & $\begin{array}{c}45,7 \% \\
(+4,2 \%)\end{array}$ & $\begin{array}{c}44,5 \% \\
(+3,0 \%)\end{array}$ & $41,5 \%$ \\
\hline Wyniki & Jarosław Kaczyński & $\begin{array}{c}35,8 \% \\
(-0,7 \%)\end{array}$ & $\begin{array}{c}33,2 \% \\
(-3,3 \%)\end{array}$ & $\begin{array}{c}34,3 \% \\
(-2,2 \%)\end{array}$ & $36,5 \%$ \\
\hline $\begin{array}{l}\text { w I turze } \\
\text { wyborów }\end{array}$ & $\begin{array}{l}\text { Różnica pomiędzy } \\
\text { B. Komorowskim } \\
\text { oraz J. Kaczyńskim }\end{array}$ & $4,9 \%$ & $12,5 \%$ & $10,2 \%$ & $5,0 \%$ \\
\hline & $\begin{array}{l}\text { Grzegorz } \\
\text { Napieralski }\end{array}$ & $\begin{array}{c}14,0 \% \\
(+0,3 \%)\end{array}$ & $\begin{array}{c}\mathbf{1 3}, \mathbf{4} \% \\
(-0,3 \%)\end{array}$ & $\begin{array}{c}\mathbf{1 3 , 5 \%} \\
(-0,2 \%)\end{array}$ & $13,7 \%$ \\
\hline
\end{tabular}

Źródło: opracowanie własne na podstawie komunikatu PKW z dnia 21.06.2010 oraz wyników prezentowanych w „Wieczorach Wyborczych” stacji TVP, Polsat News oraz TVN 24. 
Jak widać w tabeli 3, błąd w przypadku badania OBOP nie przekracza 1 punktu procentowego. Ponadto, inaczej niż w przypadku wyników MB SMG/KRC oraz IHH, dla obydwu kandydatów, którzy uzyskali największą ilość głosów błąd ma taki sam kierunek - wyniki zostały niedoszacowane. Inaczej jest w przypadku wyników MB SMG/KRC - błąd w przypadku dwóch kandydatów z największą liczbą głosów przekracza 3\%, przy czym wynik Bronisława Komorowskiego jest przeszacowany, zaś Jarosława Kaczyńskiego niedoszacowany.

Zespół profesora Domańskiego przeanalizował sondaż przeprowadzony w dniu wyborów oraz siedem sondaży zrealizowanych przez MB $\mathrm{SMG} / \mathrm{KRC}$ pomiędzy 7 a 19 czerwca i na tej podstawie doszedł do następującego wniosku: wszystkie analizowane sondaże cechuje spójność wyników, tzn. od 7 czerwca, aż do dnia wyborów sondaże MB SMG/KRC wykazywały rosnące poparcie dla Grzegorza Napieralskiego, przeszacowanie elektoratu Bronisława Komorowskiego oraz niedoszacowanie elektoratu Jarosława Kaczyńskiego ${ }^{20}$. Na tej podstawie zespół profesora Domańskiego stwierdził, iż badanie zrealizowane 20 czerwca nie zawiera błędów proceduralnych i zostało zrealizowane prawidłowo. Problem niskiej trafności sondażu MB SMG/KRC leży w doborze metody badawczej. Zdaniem komisji użycie sondażu telefonicznej do prognozowania wyników wyborów nie jest rozwiązaniem najlepszym. Komisja zaleca również, aby w przyszłości wykorzystywać do prognozowania wyłącznie metody, których skuteczność została sprawdzona ${ }^{21}$.

Jak wspominałem wcześniej, badanie Instytutu Homo Homini nie zostało uwzględnione w „Ocenie...” przygotowanej przez zespół profesora Domańskiego. Może to wynikać z dwóch faktów: Instytut Homo Homini nie jest członkiem Organizacji Firm Badania Opinii i Rynku (OFBOR), na zlecenie, której była przygotowywana „Ocena...” lub - co jest bardziej prawdopodobne - IHH odmówił poddania się ocenie. Patrząc na wyniki badania w dniu wyborów widać wyraźnie tę samą tendencję, co w przypadku sondażu MB SMG/KRC - przeszacowanie wielkości elektoratu Bronisława Komorowskiego oraz niedoszacowanie elektoratu Jarosława Kaczyńskiego.

20 Tamże, s. 36.

21 Tamże, s. 37. 


\section{II tura wyborów - 4 lipca $2010 \mathrm{r}$.}

W przypadku II tury wyborów prezydenckich badanie w dniu wyborów zostało przeprowadzone w następujący sposób: OBOP pozostał przy realizacji badania exit poll w 500 wylosowanych lokalach wyborczych, MB $\mathrm{SMG} / \mathrm{KRC}$ zdecydowało się zmienić sposób realizacji badania z telefonicznego na exit poll w 1000 wylosowanych komisji wyborczych, Instytut Homo Homini pozostał przy metodzie telefonicznej (jedyną różnicą, która została podana do publicznej wiadomości przez ten ośrodek badawczy było zwiększenie próby badawczej z 5000 wywiadów na 7500 wywiadów).

Jak widać w tabeli 4, wyniki badania zrealizowanego przez MB $\mathrm{SMG} / \mathrm{KRC}$ pomimo zastosowania metody exit poll, nadal odbiegają od wyników zaprezentowanych przez PKW (o prawie 2 punkty procentowe). Może to wynikać z faktu, iż MB SMG/KRC zastosowało liczniki o stałym skoku, niezależnie od liczby uprawnionych do głosowania w wylosowanych lokalach wyborczych. W przypadku małych komisji może się zdarzyć, iz liczba respondentów nie przekroczy np. 10 osób (przyjmując założenie: 200 uprawnionych do głosowania, frekwencja: 50\%), co w przypadku wyborów, w których mamy 10 kandydatów spowoduje, iż kandydaci, którzy w rzeczywistości uzyskają około 2\% lub mniej głosów nie zostaną w ogóle uwzględnieni w badaniu. Wydaje się również, że wpływ na to miało zastosowanie przez MB SMG/KRC w swoim badaniu licznika o skoku podawanym w literaturze przedmiotu, $\mathrm{tj}$. ankieterzy zapraszali, co najwyżej, co dziesiątego respondenta. Za takim rozwiązaniem przemawia np. liczba wywiadów zrealizowanych przez MB SMG/KRC - OBOP w 500 lokalach wyborczych zrealizował około 50000 wywiadów, zaś MB SMG/KRC w 1000 komisji zrealizowało 60000 wywiadów, co daje średnio po 100 wywiadów na jeden lokal wyborczy w przypadku OBOP oraz średnio 60 wywiadów na jeden lokal wyborczy w przypadku MB SMG/KRC.

Należy również zwrócić uwagę na fakt, iż wyniki IHH opublikowane o godzinie $20.00 \mathrm{w}$ dniu 4 lipca 2010 r. są takie same jak wyniki MB $\mathrm{SMG} / \mathrm{KRC}$. Jeśli dodatkowo przyjrzymy się frekwencji w wyborach, która również była podawana przez stacje telewizyjne (56,2\% - OBOP vs. 56,8\% - IHH) zauważymy, iż wynik IHH jest bardzo zbliżony do wyniku OBOP. Należy w tym kontekście zaznaczyć, że informacje o wyniku wyborów oraz frekwencji ukazywały się kaskadowo w poszczególnych stacjach (wyniki MB SMG/KRC zostały opublikowane w TVN po 54 sekundach od opublikowania wyników przez TVP. Również wyniki IHH zostały opublikowane w telewizji Polsat po opublikowaniu wyników OBOP.). Wydaje 
się, iż niemożliwe jest osiagnięcie dokładnie takiego samego wyniku przy użyciu dwóch zupełnie różnych metod, jak również w przypadku realizacji badania na dwóch różnych próbach. Swoje przekonanie w tym względzie opieram na serii badań porównawczych przeprowadzonych przez TNS OBOP przed rozpoczęciem współpracy z portalem Nasza Klasa, który to portal miał służyć, jako wielomilionowy panel badawczy. Takie same pytania zadano grupie respondentów biorących udział w wielotematycznym badaniu syndykatowym Omnimas ${ }^{\mathrm{TM}}$ oraz internautom zarejestrowanym na portalu Nasza Klasa. Celem było sprawdzenie, czy wyniki uzyskane na portalu internetowym można uogólnić na całą populację Polaków. Badania na różne tematy były prowadzone przez kilka miesięcy i ostatecznie zakończyły się stwierdzeniem, że pomimo uzyskania podobnych wyników, nie jest możliwe uogólnianie wyników uzyskanych na próbie internautów na całą populację ${ }^{22}$. Poza tym, w przypadku badania w dniu wyborów w grę wchodzą również różnice w konstrukcji wykorzystanego kwestionariusza, sposobie doboru próby czy liczebności próby.

Tabela 4. Zestawienie wyników sondaży zrealizowanych w dniu 4 lipca 2010 r. z wynikami PKW

\begin{tabular}{|c|c|c|c|c|c|}
\hline & & OBOP & $\begin{array}{c}\text { MB } \\
\text { SMG/KRC }\end{array}$ & IHH & PKW \\
\hline Sposób re & lizacji badania & Exit Poll & Exit Poll & CATI & - \\
\hline Wielkość & róby & ok. 50000 & 60000 & 7500 & $\longrightarrow$ \\
\hline & $\begin{array}{l}\text { Bronisław } \\
\text { Komorowski }\end{array}$ & $\begin{array}{c}\mathbf{5 3 , 1 \%} \\
(+0,09 \%)\end{array}$ & $\begin{array}{c}\mathbf{5 1 , 1 \%} \\
(-1,91 \%)\end{array}$ & $\begin{array}{c}\mathbf{5 1 , 1 \%} \\
(-1,91 \%)\end{array}$ & $53,01 \%$ \\
\hline $\begin{array}{l}\text { Wyniki } \\
\text { w I turze }\end{array}$ & Jarosław Kaczyński & $\begin{array}{c}46,9 \% \\
(-0,09 \%)\end{array}$ & $\begin{array}{c}48,9 \% \\
(+1,91 \%)\end{array}$ & $\begin{array}{c}48,9 \% \\
(+1,91 \%)\end{array}$ & $46,99 \%$ \\
\hline & $\begin{array}{l}\text { Różnica pomiędzy } \\
\text { B. Komorowskim } \\
\text { oraz J. Kaczyńskim }\end{array}$ & $6,2 \%$ & $2,2 \%$ & $2,2 \%$ & $6,02 \%$ \\
\hline
\end{tabular}

Źródło: opracowanie własne na podstawie Wirtualne Media.

Podsumowując, należy stwierdzić, że badanie realizowane za pomocą sondażu telefonicznego nie jest najlepszym sposobem, w jaki można przewidywać wynik wyborów. Przemawiają za tym następujące argu-

22 Badania były prowadzone w latach 2011-2012. Obecnie uogólnianie wyników uzyskanych w badaniach internetowych na populację generalną jest możliwe, ponieważ zostały spełnione przesłanki metodologiczne w tym zakresie. 
menty: po pierwsze, w okresie prowadzenia badania tylko nieco ponad $51 \%$ gospodarstw domowych posiadało telefony stacjonarne ${ }^{23}$. Po drugie, niższy niż w przypadku badania exit poll response rate (około 90\% w exit poll $-\mathrm{u}$ versus maksymalnie $50 \% \mathrm{w}$ badaniu CATI realizowanym na próbie numerów stacjonarnych). Po trzecie, w przypadku badania telefonicznego opieramy się wyłącznie na deklaracjach respondenta: pierwszej, że rzeczywiście już oddał głos oraz drugiej, że głos rzeczywiście oddał na osobę, którą wskazał. Oczywiście podobne deklaracje składają osoby wychodzące z lokali wyborczych, ale prawdopodobieństwo, iż przyszli oni do lokalu i nie oddali głosu jest mniejsze niż w przypadku badania telefonicznego. Potwierdzają to np. dane Państwowej Komisji Wyborczej - w pierwszej turze wyborów prezydenckich wydano prawie 1,7 miliona kart, zaś do urn nie trafiło trochę ponad 5 tysięcy. Po czwarte, w przypadku badania telefonicznego występuje także tzw. efekt ankieterski, tj. mniejszy lub większy wpływ ankietera na respondenta. W rozmowie $\mathrm{z}$ ankieterem respondent może udzielać takiej odpowiedzi, jaka jest jego zdaniem oczekiwana. Efekt ten jest np. widoczny w sondażach telefonicznych $\mathrm{MB}$ SMG/KRC realizowanych przed wyborami oraz w dniu 20 czerwca 2010 r. (przeszacowanie elektoratu Bronisława Komorowskiego) czy w jednym z sondaży realizowanych przez PBS na zlecenie Gazety Wyborczej, z którego wynikało, że Bronisław Komorowski powinien wygrać w I turze. I wreszcie, po piąte ważny jest również sposób sformułowania pytań zadawanych respondentowi.

W przypadku badania exit poll nie występuje efekt ankieterski, respondent otrzymuje ankietę, która do złudzenia przypomina kartę do głosowania, jedyną różnicą są zmienne demograficzne (m.in. płeć, wiek, wykształcenie) oraz pytanie o preferencje partyjne, a w przypadku drugiej tury wyborów pytanie, na kogo respondent oddał głos w pierwszej turze. Ankieta po wypełnieniu jest przez respondenta wrzucana do urny. Drugą ważną sprawą jest zwrócenie uwagi, iż nie opieramy się na deklaracjach, a pytamy respondenta o zwrócenie uwagi, którą zrobił chwilę wcześniej. Równie ważne jest, iż respondent nie odpowiada na pytania, a jedynie zakreśla nazwisko kandydata, czyli de facto robi to samo, co zrobił chwilę wcześniej w lokalu wyborczym.

Obydwu tych metod nie można porównywać w stosunku do siebie, można jedynie porównać wyniki, jakie uzyskujemy w wyniku przeprowadzenia obydwu badań. A wyniki przemawiają za stosowaniem dobrze zorganizowanego badania exit poll.

23 Rocznik statystyczny GUS 2012, s. 13. 
Tabela 5. Wyniki badań prezydenckich exit poll i late poll przeprowadzonych w $2010 \mathrm{r}$. - I tura

\begin{tabular}{|l|c|c|c|}
\hline & EXIT POLL & PKW & $\begin{array}{c}\text { RÓŻNICA } \\
\text { PKW - OBOP }\end{array}$ \\
\hline Komorowski Bronisław & $41,20 \%$ & $41,54 \%$ & $0,34 \%$ \\
\hline Kaczyński Jarosław & $35,80 \%$ & $36,46 \%$ & $0,66 \%$ \\
\hline Napieralski Grzegorz & $13,50 \%$ & $13,68 \%$ & $0,18 \%$ \\
\hline Korwin-Mikke Janusz & $3,00 \%$ & $2,48 \%$ & $-0,52 \%$ \\
\hline Pawlak Waldemar & $1,90 \%$ & $1,75 \%$ & $-0,15 \%$ \\
\hline Olechowski Andrzej & $1,60 \%$ & $1,44 \%$ & $-0,16 \%$ \\
\hline Jurek Marek & $1,30 \%$ & $1,06 \%$ & $-0,24 \%$ \\
\hline Lepper Andrzej & $1,20 \%$ & $1,28 \%$ & $0,08 \%$ \\
\hline Ziętek Bogusław & $0,30 \%$ & $0,18 \%$ & $-0,12 \%$ \\
\hline Morawiecki Kornel & $0,20 \%$ & $0,13 \%$ & $-0,07 \%$ \\
\hline
\end{tabular}

Źródło: opracowanie własne na podstawie OBOP, PKW.

Tabela 6. Wyniki badań prezydenckich exit poll i late poll przeprowadzonych w $2010 \mathrm{r}$. - II tura

\begin{tabular}{|l|c|c|c|}
\hline & EXIT POLL & PKW & $\begin{array}{c}\text { RÓŻNICA } \\
\text { PKW - OBOP }\end{array}$ \\
\hline Kaczyński Jarosław & $46,90 \%$ & $46,99 \%$ & $0,09 \%$ \\
\hline Komorowski Bronisław & $53,10 \%$ & $53,01 \%$ & $-0,09 \%$ \\
\hline
\end{tabular}

Źródło: opracowanie własne na podstawie OBOP, PKW

\section{Bibliografia}

Blalock H.M., Statystyka dla socjologów, Warszawa 1977.

Domański H. (przewodniczący komisji), Ocena metodologii i rezultatów badań poprzedzających pierwszą i drugą turę wyborów prezydenckich w 2010 roku, Warszawa 2010.

Hilmer R., Exit Polls - A Lot More than Just a Tool for Election Forecasts, [w:] Carballo M., Hjelmar U. (red.), Public Opinion Polling in a Globalized World, Berlin 2008.

Sztabiński P.B., Sawiński Z., Sztabiński F. (red.), Nowe metody, nowe podejścia badawcze $w$ naukach społecznych, Warszawa 2004.

Sztabiński P.B., Sawiński Z., Sztabiński F. (red.), Fieldwork jest sztuka. Jak dobrać respondenta, sktonić do udziału w wywiadzie, rzetelnie i sprawnie zrealizować badanie, Warszawa 2005. 